\title{
Temperature Field in MIG Welding of Thin Plate of Stainless Steel
}

Trường nhiệt độ khi hàn MIG tấm mỏng thép không gỉ

\author{
Luu Van Hung ${ }^{1}$, Nguyen Tien Duong ${ }^{2 *}$ \\ ${ }^{I}$ The Industrial Safety Technical Aid Centre, Hanoi, Vietnam \\ ${ }^{2}$ Hanoi University of Science and Technology, Hanoi, Vietnam \\ "Email: duong.nguyentien@hust.edu.vn
}

\begin{abstract}
This paper studies the butt welded joint of SUS316L stainless steel. The butt joint is not beveled, has a gap and is welded in one pass by MIG welding process. First, the welding parameters of this weld are determined through calculation and test welding for the butt joint of two plates of $3 \mathrm{~mm}$ in thickness. Then these welding parameters are used as input data to calculate and determine the temperature field by two methods: the calculation method based on the theory of heat transfer process and the numerical simulation method of welding processes that relies on SYSWELD software on the basis of the finite element method. The calculation results of the two methods were compared with each other and tested by experiment to show the reliability of calculation and simulation results.
\end{abstract}

Keywords: Butt weld, MIG welding, stainless steel, SUS316L, temperature field.

Tóm tắt

Bài báo này nghiên cưu liên kết hàn giáp mối tấm mỏng vật liệu thép không gỉ SUS316L. Liên kết giáp mối không vát mép, có khe hở và được hàn một lượt bằng quá trình hàn MIG. Trước tiên, bộ thông số chế độ hàn của mối hàn này được xác định thông qua tính toán và hàn thử nghiệm cho liên kết hàn giáp mối tấm dày 3 $\mathrm{mm}$. Sau đó bộ thông số chế độ hàn này được sử dụng để đưa vào tính toán xác định trường nhiệt độ theo theo hai phương pháp: phương pháp tính toán dựa trên lý thuyết của quá trình truyền nhiệt và phương pháp mô phỏng số quá trình hàn dựa vào phần mềm SYSWELD trên cơ sở của phương pháp phần tử hữu hạn. Kết quả tính toán của hai phương pháp được so sánh với nhau và được kiểm nghiệm bằng thực nghiệm để từ đó cho thấy độ tin cậy của kết quả tính toán và mô phỏng.

Từ khóa: Butt weld, MIG welding, stainless steel, SUS316L, temperature field.

\section{Introduction}

The SUS316L austenite stainless steel is a heatresistant material with high corrosion resistance. This material is widely used in many industry sectors: chemical, petrochemical and food industries.

The butt joint of stainless steel can be realized by the various welding processes such as metal inert gas welding (MIG welding), tungsten inert gas welding (TIG welding), shielded metal arc welding (SMAW), submerged arc welding (SAW),... In these methods, the MIG welding process is popularly used to weld the thin plate of stainless steel in general and SUS316L stainless steel in particular because it produces high quality welds, high productivity, and low cost.

The welding temperature field has a decisive influence on the properties of the weld such as the appearance of residual stress and deformation of the weld, weld shape and size, weld metal structure, and the heat-effected zone,... These factors all affect the quality of welds as well as the working ability of welded structures.

The calculation of welding temperature field according to the theory of the heat transfer process gives reliable results and it is utility, but it is only correct when ensuring the assumptions of the applied theories. Sometimes these assumptions are different from reality, for example, it is assumed that the coefficients of material no change with temperature. In this study, the authors calculated the temperature field in MIG welding of butt joint of two SUS316L stainless steel plates of $3 \mathrm{~mm}$ in thickness according to the theory of heat transfer. Then, the finite element method (FEM) based on SYSWELD software [1] is used to simulate and determine welding temperature field during MIG welding between two stainless steel plates mentioned above. Finally, an experimental study of measuring the temperature field during MIG welding on real samples with the same material and same dimensions was performed.

ISSN 2734-9381

https://doi.org/10.51316/jst.154.etsd.2021.31.5.12

Received: November 4, 2020; accepted: January 12, 2021 


\section{Calculation of Temperature Field Based on Heat Transfer Theory}

\subsection{Temperature Field in Thin Plate Welding}

In welding of thin plate, it is assumed that the temperature along plate thickness is constant; the distribution of thermal field is the same on both sides of the plate. According to the theory of heat transfer in welding, for arc welding of steel material, the plate can be considered as a thin plate if its thickness is less than $20 \mathrm{~mm}$ [2]. For the MIG welding process, if the plate thickness is equal to or less than $5 \mathrm{~mm}$, it is considered as a thin plate.

The temperature remains constant with the plate thickness, so the heat conduction is two-dimensional. The welding temperature field can be obtained from the fundamental differential equation for heat conduction in the case of two dimensions:

$$
\frac{\partial T}{\partial t}=a\left[\frac{\partial^{2} T}{\partial x^{2}}+\frac{\partial^{2} T}{\partial y^{2}}\right]
$$

with: $T$ - temperature; $t$ - time;

$$
\begin{aligned}
& x, y \text { - heat flow direction; } \\
& a \text { - thermal diffusivity: } a=\lambda / c . \rho ; \\
& \lambda \text { - thermal conductivity; } \\
& \rho \text { - density; } c \text { - specific heat. }
\end{aligned}
$$

The temperature distribution at the pseudo-steady is obtained by Rosenthal $[3,4,5]$ :

$$
T-T_{0}=\frac{q_{0} / d}{4 \pi \lambda} \exp \left(-\frac{V x}{2 a}\right) \mathrm{K}_{0}\left(\frac{V r}{2 a}\right)
$$

where: $q$ - net power of heat source;

$$
\begin{aligned}
& d \text { - plate thickness; } \\
& V \text { - welding speed; }
\end{aligned}
$$

$K_{0}(U)$ - modified Bessel function of the second kind and zero order with $U=\frac{v r}{2 a}$;

$$
r \text { - radius vector, } r=\sqrt{x^{2}+y^{2}} \text {. }
$$

The equation (2) is transformed into dimensionless equation.

$$
\frac{\theta \delta}{n}=\exp (-\xi) \mathrm{K}_{0}\left(\sigma_{5 m}\right)
$$

where: $\theta$ - dimensionless temperature,

$$
\begin{aligned}
& \theta=\frac{\left(T-T_{0}\right)}{\left(T_{c-} T_{0)}\right.} \text { and } \delta=\frac{V d}{2 a} \\
& T_{0} \text { - initial temperature; }
\end{aligned}
$$

$$
\begin{aligned}
& T_{c} \text { - reference temperature; } \\
& \delta \text { - dimensionless plate thickness; } \\
& n \text {-dimensionless parameter: }
\end{aligned}
$$

$$
n=\frac{q V}{4 \pi a^{2} \rho c\left(T_{c-} T_{0}\right)}=\frac{q V}{4 \pi a^{2}\left(H_{c-} H_{0}\right)}
$$

where: $\left(\mathrm{H}_{\mathrm{c}}-\mathrm{H}_{0}\right)$ - heat content per unit volume at reference temperature.

$$
\begin{aligned}
& \xi, \Psi \text { - dimensionless coordinates of } x \text { and } y \\
& \sigma \text { - dimensionless radius vector: } \\
& \xi=\frac{V x}{2 a} ; \text { (a) } \Psi=\frac{V y}{2 a} ; \text { (b) } \sigma=\frac{V r}{2 a} \text { (c) }
\end{aligned}
$$

In welding of thin plate, the temperature does not vary with plate thickness. Then the isothermal contours of thin plate are drawn in the $O X Y$ plane. The form of isothermal enclosure of a thin plate is shown in Fig. 1 [5].

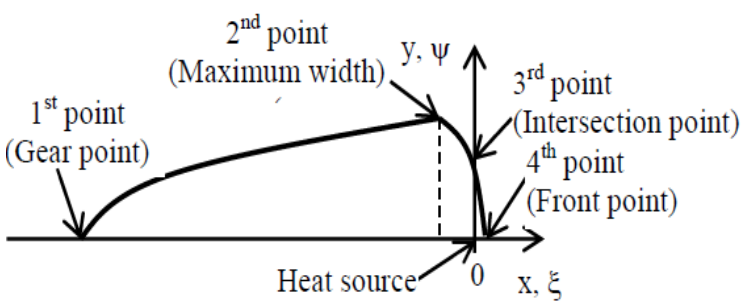

Fig. 1. Isothermal enclosure of thin plate.

The maximum width of an isothermal contour $\left(2^{\text {nd }}\right.$ point $)$ is obtained by taking $(\partial \delta / n) / \partial \xi=0$ :

$$
\xi_{m}=-\sigma_{5 m} \frac{K_{0}\left(\sigma_{5 m}\right)}{K_{1}\left(\sigma_{5 m}\right)}
$$

By replacing (7) into (3) and after resolving, we get the width of isothermal contour:

$$
\Psi_{m}=\sigma_{5 m} \sqrt{1-\left[K_{0}\left(\sigma_{5 m}\right)\right]^{2} /\left[K_{1}\left(\sigma_{5 m}\right)\right]^{2}}
$$

To find the intersection point of isothermal contour with $\Psi$ axis ( $3^{\text {rd }}$ point), putting $\xi_{m}=0$ and replacing these values into (3), we obtain:

$$
\frac{\theta \delta}{n}=\mathrm{K}_{0}\left(\Psi_{m}\right)
$$

After solving this equation, the value of $\Psi_{m}$ is obtained.

To obtain the front point $\left(\xi^{\prime}\right)\left(4^{\text {th }}\right.$ point) and rear point ( $\xi$ ") ( $1^{\text {st }}$ point) of isothermal contour, the value $\sigma= \pm \xi$ is replaced into (3):

$$
\left(\xi^{\prime}\right)=\ln \left(\frac{n K_{0}\left(\xi^{\prime}\right)}{\theta \delta}\right) \text { with }\left(\xi^{\prime}\right)>0
$$


and $\left(\xi^{\prime \prime}\right)=\ln \left(\frac{n K_{0}\left(\xi^{\prime \prime}\right)}{\theta \delta}\right)$ with $\left(\xi^{\prime \prime}\right)<0$

The distance from the maximum width of the fusion boundary $\left(Y_{I}\right)$ to the maximum width of the boundary of crystallization temperature $\left(Y_{2}\right)$ is the width of the heat affected zone (HAZ):

$$
H A Z=Y_{2}-Y_{1}
$$

\subsection{Numerical Application}

Consider MIG welding of butt joint of two SUS316L stainless steel plates, the dimensions of each plate are: $250 \mathrm{~mm} \times 100 \mathrm{~mm} \times 3 \mathrm{~mm}$ (length $\mathrm{x}$ width $\mathrm{x}$ thickness). Material properties of this steel are given in Table 1. The joint is not beveled; the welding gap is $1.5 \mathrm{~mm}$ [6]. The initial temperature $\left(\mathrm{T}_{0}\right)$ is $30^{\circ} \mathrm{C}$.

The welding parameters for this weld joint are presented in Table 2 .

The isothermal contours are symmetrical across the weld line because the two plates are similar in material and size. So the isothermal contours only need to be drawn in haft of them.

Table 1. Material properties of stainless steel SUS 316L [4,7]

\begin{tabular}{|c|c|c|}
\hline Parameter & Unit & Value \\
\hline $\mathrm{a}$ & $\mathrm{mm}^{2} / \mathrm{s}$ & 4 \\
\hline$\lambda$ & $\mathrm{W} / \mathrm{mm}^{\circ} \mathrm{C}$ & 0.02 \\
\hline $\mathrm{H}_{\mathrm{c}}-\mathrm{H}_{0}$ & $\mathrm{~J} / \mathrm{mm}^{3}$ & 7.4 \\
\hline $\mathrm{T}_{\mathrm{m}}$ & ${ }^{\circ} \mathrm{C}$ & 1450 \\
\hline $\mathrm{T}_{\mathrm{A} 1}$ & ${ }^{\circ} \mathrm{C}$ & 800 \\
\hline
\end{tabular}

Table 2. Welding parameters for butt weld of SUS316L stainless steel with the thickness of $3 \mathrm{~mm}$

\begin{tabular}{|c|c|c|c|}
\hline Parameters & $I_{h}(\mathrm{~A})$ & $U_{h}(\mathrm{~V})$ & $V_{h}(\mathrm{~mm} / \mathrm{s})$ \\
\hline Layer 1 & 120 & 23 & 5 \\
\hline
\end{tabular}

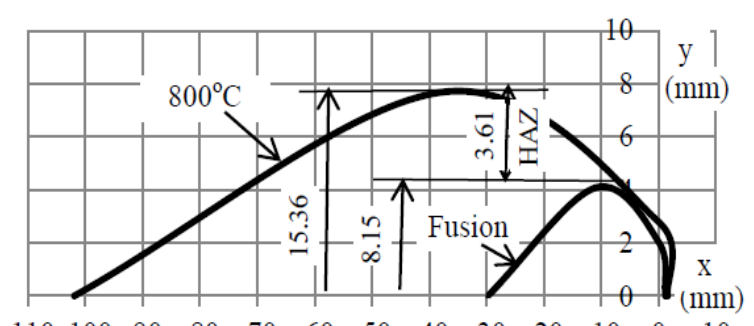

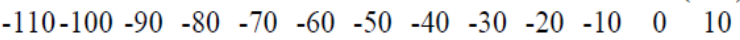

Fig. 2. Isothermal contour at the fusion and isothermal contour at $800^{\circ} \mathrm{C}$ in plate plane.
By using formula in the section 2.1 to calculate, the isothermal contour at the fusion temperature of $1450{ }^{\circ} \mathrm{C}[4,8]$ and the isothermal contour at the phase transformation temperature of $800{ }^{\circ} \mathrm{C}$ of SUS316L in the plate plane are obtained (Fig. 2) and the results are presented in Table 3 . The weld width is $8.15 \mathrm{~mm}$. The maximum width of boundary of phase transformation temperature is $15.36 \mathrm{~mm}$. So that, the width of heat affected zone is $3.61 \mathrm{~mm}$.

\section{Simulation by Finite Element Method}

\subsection{Finite Element Model}

The SYSWELD software [5] is used to simulate the MIG welding process of butt joint. The dimensions and material of the sample are the same as in the calculation above. The welding parameters are used the same as in section 2.2.

The 3D elements of 8-node bricks are used to model this weld joint. We use the Visual-Mesh module of Sysweld software to build. The model of this joint is built with 98452 nodes and 127504 elements. The straight weld path is built according to the requirements of stainless steel welding. The element mesh in $X O Z$ plane is presented in Fig. $3 \mathrm{a}$ and Fig. 3b. The element mesh in $X O Y$ plane is presented in Fig. 4a and Fig. 4b.

\subsection{Simulation Results}

First, the welding parameters are preliminarily determined based on theory and handbook [9, 10]. Then these welding parameters are put in the simulation by the SYSWELD software to correct them so that the weld meets the required shape and size. Finally, these welding parameters are used to test welding and final correction to obtain reasonable welding parameters.

The temperature field in section across (in $\mathrm{XOZ}$ plane) of the weld joint is shown in Fig. $3 \mathrm{a}$ and Fig. $3 \mathrm{~b}$. Fig. 3a shows the fusion boundary in the $X O Z$ plane while Fig. $3 \mathrm{~b}$ gives the isothermal contour at $800{ }^{\circ} \mathrm{C}$. These two isothermal contours cannot be shown in the same figure because, at the cross-section where the width of the fusion boundary is maximal, the width of the isothermal contour at $800{ }^{\circ} \mathrm{C}$ is not maximal. The widest place of the isothermal contour at $800{ }^{\circ} \mathrm{C}$ is behind this cross-section. It means that the lower the temperature is, the farther the widest place of the isothermic contour locates back of the center of the heat source. This is shown very clearly in Fig. 4b.

Fig. $3 \mathrm{a}$ indicates that the weld ensures complete fusion and complete penetration. The weld does not have defects as undercut, overlap, excessive penetration. The weld meets the desired size and shape requirements. This confirms that the welding parameters in Table 2 are reasonable. 
The temperature field in the plate plane (XOY plane) of the weld joint is shown in Fig. $4 \mathrm{a}$ and $4 \mathrm{~b}$. The sizes and the shape of weld pool and the boundary of phase transformation temperature (at $800{ }^{\circ} \mathrm{C}$ ) were measured from these figures. The basic dimensions of the weld pool are found in Fig. 4a: the width of the weld pool is $5.9 \mathrm{~mm}$, the length of the weld pool is $18.93 \mathrm{~mm}$. The basic dimensions of the contour at the phase transformation temperature (at $800{ }^{\circ} \mathrm{C}$ ) are indicated in Fig. 4b: the maximum width of the contour at the phase transformation temperature is $14.44 \mathrm{~mm}$, the length of this contour is $70.6 \mathrm{~mm}$.

The width of heat affected zone is deduced from the equation (12): $\mathrm{HAZ}=4.27 \mathrm{~mm}$.

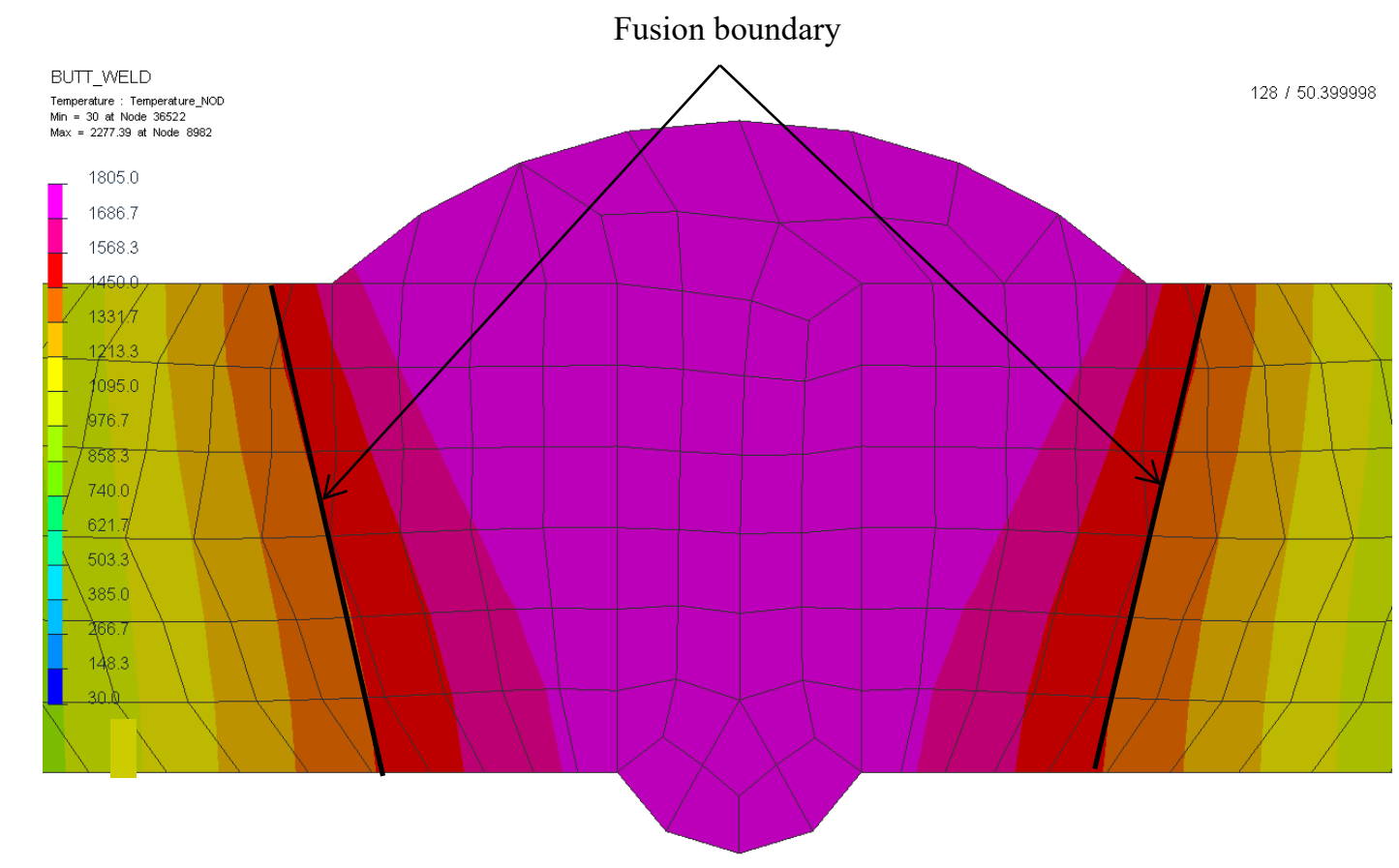

(a)

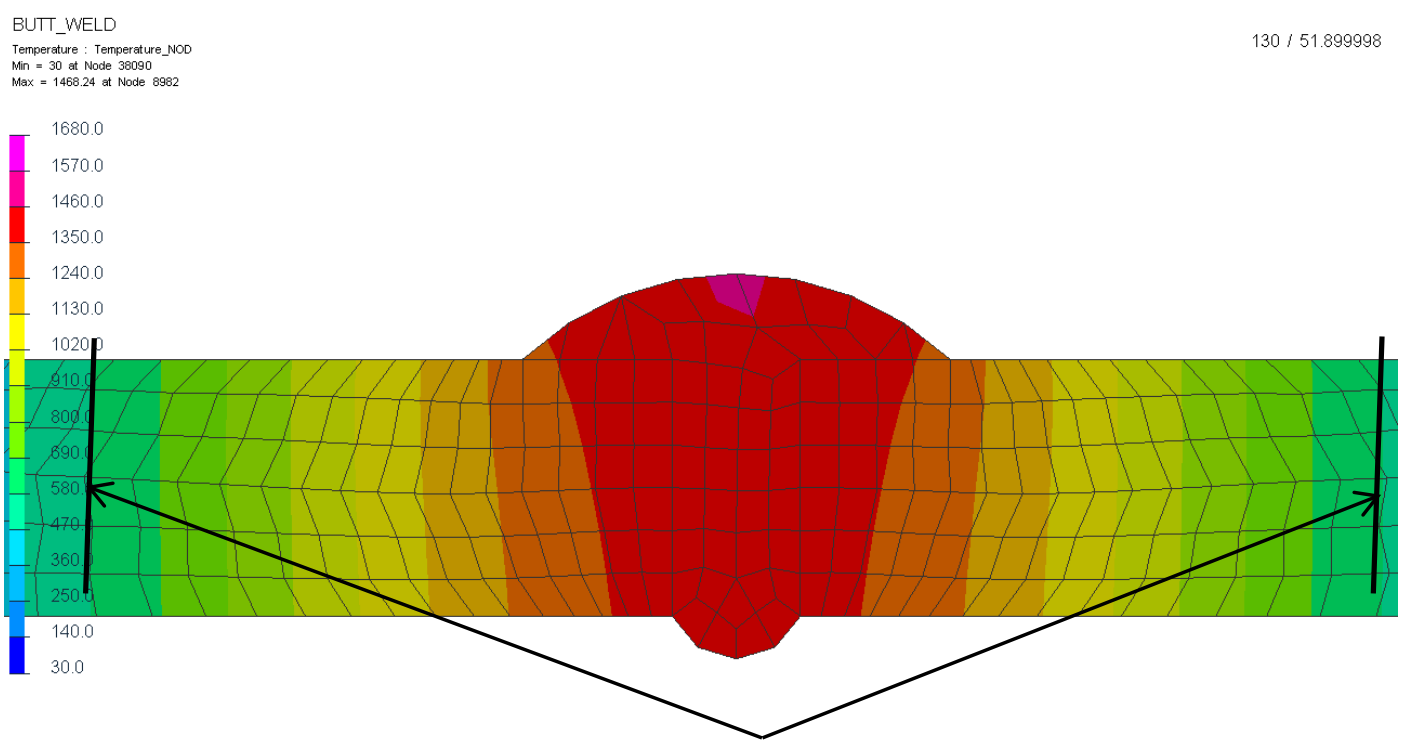

Boundary at $800^{\circ} \mathrm{C}$

(b)

Fig. 3. (a) Fusion boundary in $X O Z$ plane, (b) Isothermal boundary at $800{ }^{\circ} \mathrm{C}$ in $X O Z$ plane. 
JST: Engineering and Technology for Sustainable Development

Volume 31, Issue 5, November 2021, 081-088

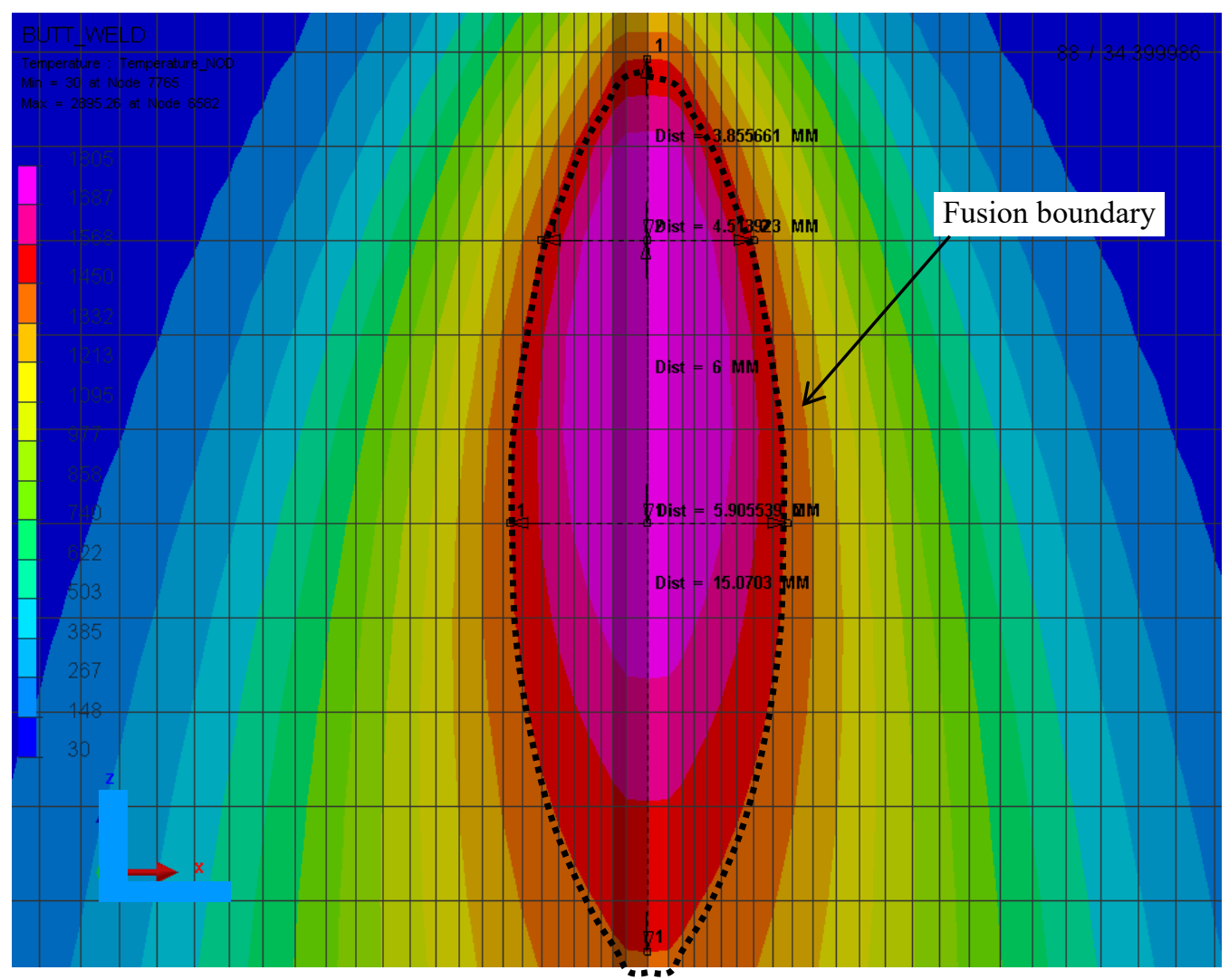

(a)

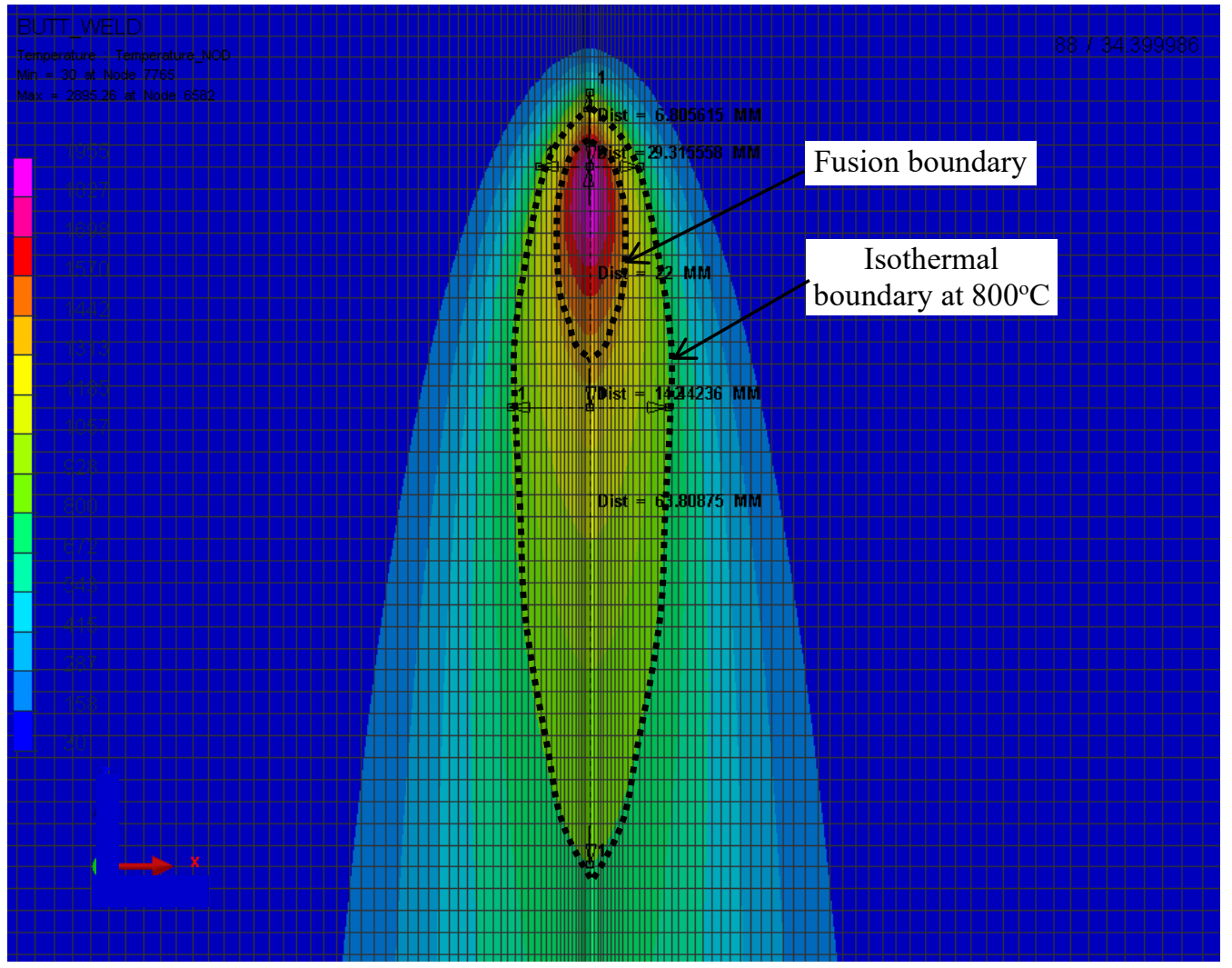

(b)

Fig. 4. (a) Dimensions of fusion boundary in $X O Y$ plan. (b) Isothermal boundaries in $X O Y$ plan. 

Table 3.

The obtained results are presented in Fig. 5 and

Now, we consider the temperature cycles at 4 points (Fig. 6): Point 1 - Node 3204 (at heat source center); Point 2 - Node 19374 (maximum temperature of $1423{ }^{\circ} \mathrm{C}$ - near fusion boundary); Point 3 - Node 19361 (maximum temperature of $774{ }^{\circ} \mathrm{C}$ - near structure transformation temperature); Point 4 - Node 19432 (at the base metal that has a maximum temperature of $488^{\circ} \mathrm{C}$ ).

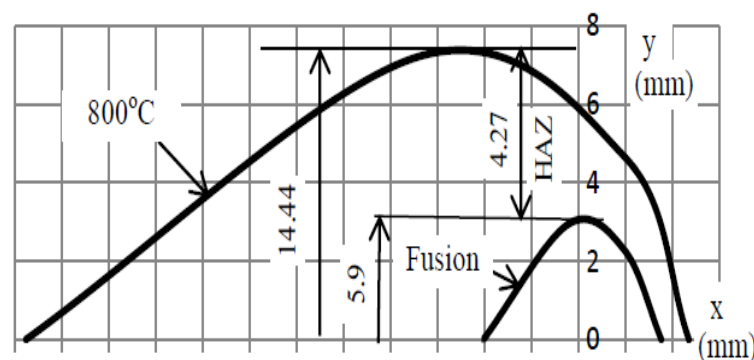

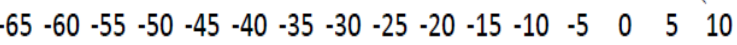

Fig. 5. Fusion boundary and isothermal boundary at $800{ }^{\circ} \mathrm{C}$ in FEM.

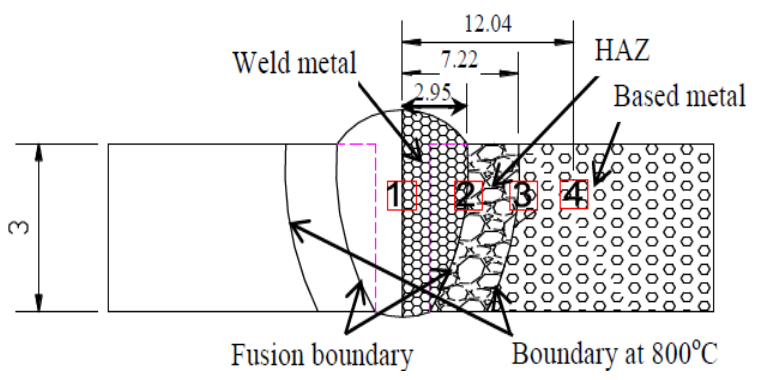

Fig. 6. Four survey points.

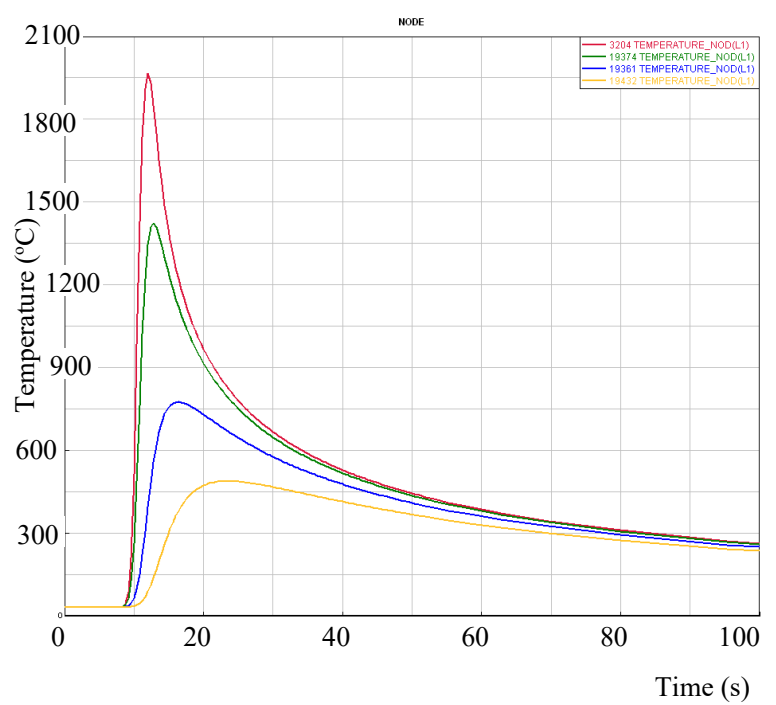

Fig. 7. Temperature cycles at 4 survey points.

The temperature cycles at these 4 points are given in Fig. 7. These temperature cycles are determined after 10.8 seconds (the welded length is $54 \mathrm{~mm}$ ). The maximum temperature at the heat source center (node
3204) reaches $1932{ }^{\circ} \mathrm{C}$. But only 10 seconds after, this temperature reduces to $900{ }^{\circ} \mathrm{C}$. It means that the cooling rate at this point is very high (about $\left.103.2^{\circ} \mathrm{C} / \mathrm{s}\right)$. While the temperature at node 19432 (12.04 mm from weld center) decreases from $488{ }^{\circ} \mathrm{C}$ to $447^{\circ} \mathrm{C}$ after 10 seconds (cooling rate $=4.1^{\circ} \mathrm{C} / \mathrm{s}$ ).

For node 19374 , the maximum temperature of this node is $1423{ }^{\circ} \mathrm{C}$ and the temperature at this node reduces to $812^{\circ} \mathrm{C}$ after 10 seconds. The cooling rate in this node at that time was about $61.1^{\circ} \mathrm{C} / \mathrm{s}$. Finally, the maximum temperature of node 19361 is $774{ }^{\circ} \mathrm{C}$ and it is $630^{\circ} \mathrm{C}$. The cooling rate in this node at that time was about $14.4{ }^{\circ} \mathrm{C} / \mathrm{s}$.

\section{Experiment}

The test welding sample is the same as in the theoretical calculation and in the modeling: The material is SUS316L stainless steel, sizes of each plate are $250 \mathrm{~mm} \times 100 \mathrm{~mm} \times 3 \mathrm{~mm}$. The welding parameters for experimental welding are the same as in the theoretical calculation and in the modeling.

The experiment model of temperature measurement by the thermal sensor during welding is shown in Fig. 8. These sensors are posited near the outer boundary of HAZ to find the point that has the maximal temperature of $800{ }^{\circ} \mathrm{C}$. The sensors measure and send feedback in the form of voltage to the amplifier unit. The amplifier unit receives the signal from the sensors, it amplifies and then feeds the signal into the microcontroller block. The microcontroller unit receives the signal from the amplifier unit and controls the display unit. The display unit will display the temperature values that are measured from the temperature sensor through the led screen.

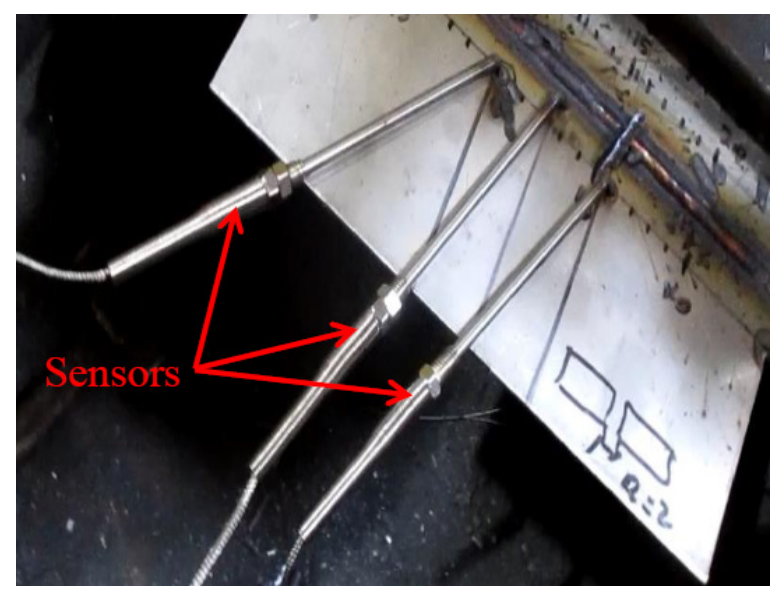

Fig. 8. Temperature measurement by thermal sensor.

The weld width (Fig. 9) and the width of heataffected zone (Fig. 8) are measured and presented in Table 3. The weld width is $6.5 \mathrm{~mm}$. The maximum width of isotherm enclosure at $800{ }^{\circ} \mathrm{C}$ is $15 \mathrm{~mm}$. Hence, the width of heat-affected zone is $4.25 \mathrm{~mm}$. 


\section{Results and Discussions}

The weld width (or the width of weld pool), the maximum width of isotherm enclosure at $800{ }^{\circ} \mathrm{C}$ and the width of heat affected zone in three methods (calculation, FEM and experiment) are synthesized in Table 3.

Table 3. Obtained results in three methods

\begin{tabular}{|l|c|c|c|}
\hline Parameters & Theory & FEM & Experiment \\
\hline Weld width (mm) & 8.15 & 5.9 & 6.5 \\
\hline $\begin{array}{l}\text { Maximum width of } \\
\text { isotherm enclosure } \\
\text { at } 800^{\circ} \mathrm{C}(\mathrm{mm})\end{array}$ & 15.36 & 14.44 & 15 \\
\hline $\begin{array}{l}\text { Width of HAZ } \\
\text { (mm) }\end{array}$ & 3.61 & 4.27 & 4.25 \\
\hline $\begin{array}{l}\text { Length of weld } \\
\text { pool (mm) }\end{array}$ & 30.96 & 18.93 & - \\
\hline $\begin{array}{l}\text { Length of isotherm } \\
\text { enclosure at } 800^{\circ} \mathrm{C} \\
\text { (mm) }\end{array}$ & 103.5 & 70.6 & - \\
\hline
\end{tabular}

The isothermal contours at the fusion temperature of theoretical calculation and FEM are given in Fig. 10. The weld width in the theoretical calculation $(8.15 \mathrm{~mm})$ is greater than that in FEM $(5.9 \mathrm{~mm})$. The experimental value of weld width $(6.5 \mathrm{~mm})$ is between the values of theoretical calculation and FEM. The difference in weld width between the result of FEM and experimental result is small. The weld pool length in the theoretical calculation $(30.96 \mathrm{~mm})$ is much larger than that in FEM $(18.93 \mathrm{~mm})$. The distance from the heat source center to the front point of the isothermal enclosure in FEM $(3.86 \mathrm{~mm})$ is larger than that in the theoretical calculation $(1.2 \mathrm{~mm})$.

The isothermal boundaries at $800{ }^{\circ} \mathrm{C}$ in theoretical calculation and FEM are given in Fig. 11 . The difference between the maximum width of isothermal boundaries in three methods is small $(15.36 \mathrm{~mm}$ in theoretical calculation compared to $14.44 \mathrm{~mm}$ in FEM and $15 \mathrm{~mm}$ in experiment). The length of isothermal boundary at $800{ }^{\circ} \mathrm{C}$ in theoretical calculation $(103.5 \mathrm{~mm})$ is much bigger than that in FEM $(70.6 \mathrm{~mm})$. The distance from the heat source center to the front point of the isothermal enclosure in FEM $(6.8 \mathrm{~mm})$ is much higher than that in theorical calculation $(1.6 \mathrm{~mm})$.

The width of heat affected zone in the theoretical calculation $(3.61 \mathrm{~mm})$ is smaller than that in FEM $(4.27 \mathrm{~mm})$. The result of width of heat affected zone in FEM is very close to that in the experiment $(4.27 \mathrm{~mm}$ is compared to $4.25 \mathrm{~mm}$ ).

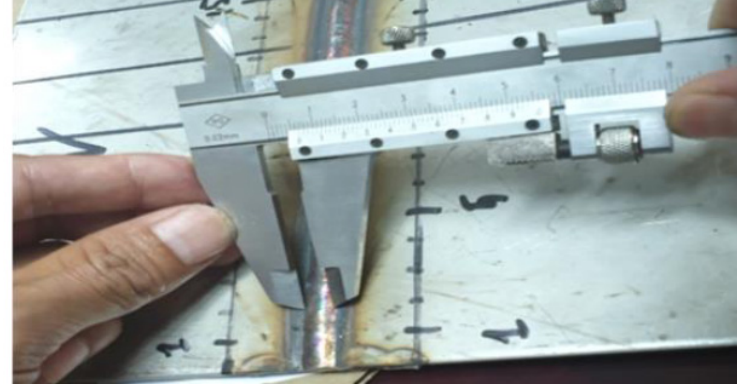

Fig. 9. Measurement of weld width.

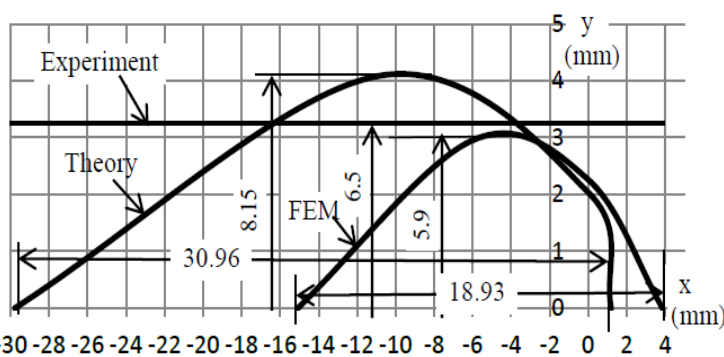

Fig. 10. Isothermal contours at the fusion temperature of theorical calculation and of simulation.

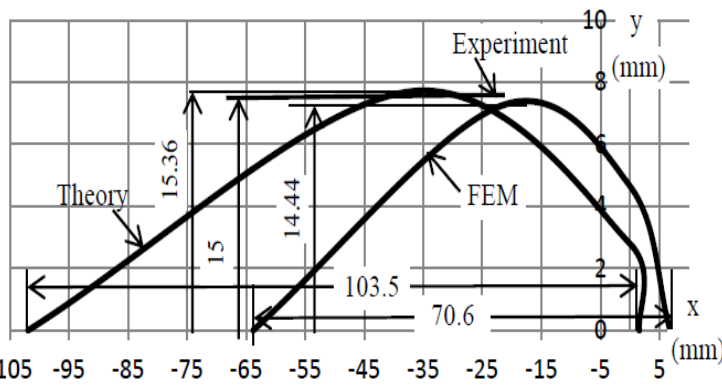

Fig. 11. Isothermal boundaries at $800^{\circ} \mathrm{C}$ of theoretical calculation and simulation.

\section{Conclusion}

In this study, the width of fusion boundary (weld width) and the width of heat affected zone in weld butt of SUS316L stainless steel plates of $3 \mathrm{~mm}$ in thickness are determined by three methods (theoretical calculation, simulation, and experiment). The research results indicated that the results of FEM are very close to the experiment results; there is a big difference between the results of theoretical calculation and the results of FEM or the results of the experiment. This can be explained because in the theoretical calculation some of the assumptions are assumed. For example, with the assumption of thin plate, the temperature does not change with the plate thickness and the coefficients of the material does not change (thermal diffusion, thermal conductivity, density,...).

The research showed the correctness as well as the reliability of the simulation results by FEM based on SYSWELD software. By using FEM, the temperature cycle at any point and the temperature field in welding are determined. 
This research determined the temperature field in MIG welding of SUS316L stainless steel material. In a similar way, it is possible to determine the temperature field for any given material with different welding processes.

The calculation of the welding temperature field is the basis to choose the appropriate welding parameters to achieve a high-quality weld. In addition, the determination of the welding temperature field plays an important role to determine residual stress, welding deformation, and microstructure of the welded joint.

\section{References}

[1] ESI Group, Sysweld 2017 - Reference Manual: Description of the mathematical model, data input and computation procedures, January, 2017.

[2] I.P. Trochun, Internal forces and deformations during welding, State Scientific and Technical Publishing House of Machine-Building Literature, Moscow, 1964 (Orginal text in Russian).

[3] Nguyen The Ninh, Welding heat transfer analysis and applications, Bach Khoa Publishing House, Hanoi, 2008 (Orginal text in Vietnamese).

[4] Nguyen Tien Duong, Determination of Temperature distribution during mig welding in fillet weld joint between two thin plates of cacbon steel and stainless steel, Proceedings of the $13^{\text {th }}$ SEATUC Symposium (2019), pp. 18-23.

[5] Systein Grong, Metallurgical modeling of welding, Institute of Materials, 1 Carlton House Terrace, London, SW 1 Y 5 DB, UK, 1997. 605, 1997.

[6] American Welding Society, AWS D1.6: 2015 Structural Welding Code - Stainless steel. 550N.W. LeJeune Road, Miami, Florida 33126.

[7] International Welding Engineer (IWE), Module 2: Materials and their behaviour during welding, International Institute of Welding (IIW), GSISLVDuisburg, 2015.

[8] Ngo Le Thong, Fusion electric welding technology Volume 2: Application, Science and Technics Publishing House, 2005 (Orginal text in Vietnamese).

[9] Ngo Le Thong, Fusion electric welding technology Volume 1: Theoretical Foundations, Science and Technics Publishing House, 2004 (Orginal text in Vietnamese).

[10] Hoang Tung, Nguyen Thuc Ha, Ngo Le Thong, Chu Van Khang, Welding Manual, $6^{\text {th }}$ edition, Science and Technics Publishing House, 2006 (Orginal text in Vietnamese). 